\title{
A Back-Door Entrance into Teaching Teachers
}

\author{
Pulane Lefoka ${ }^{1}$ \\ ${ }^{1}$ Independent Consultant, Lesotho \\ Correspondence: Pulane Lefoka, Independent Consultant, Lesotho. ORCID ID: 000-0001-7549-1754
}

Received: February 24, 2021; Accepted: March 25, 2021; Published: March 26, 2021

\begin{abstract}
This paper is based on $\mathrm{PhD}$ research that was carried out at the National University of Lesotho's Faculty of Education. The focus of the study was on the sources and application of professional knowledge among teacher educators. The content of the paper was drawn from the Chapter of the theses which presented findings on enactment of professional knowledge. Eight teachers participated in the study. All entered the teacher educators' world through the backdoor; that is, some were invited by their teacher educators to work as teaching assistants while others applied to an advertised position. None of them had teaching in higher education credentials, hence my claim: back-door entrance. Their major source of professional knowledge is experiential and their professional lives have been shaped by their context. However, practice-based knowledge presents numerous challenges including lack of knowledge of the pedagogy of teaching student-teachers and bias towards using transmissive methods of teaching instead of interactive ones. The study concludes that teacher educators who participated in the study would benefit from enrolling in higher education programmes that would equip them with higher education knowledge and skills in the context of teaching student-teachers.
\end{abstract}

Keywords: teacher educator, student-teacher, enactment of professional knowledge, practical knowledge, pedagogy, phronesis, teaching teaching and learning

\section{Introduction}

This paper shares the findings of a study which was carried out at the National University of Lesotho's (NUL) Faculty of Education. The study focused on teacher educators based in the Faculty. In undertaking the study there was an observation that teacher education institutions experience of having to hire teacher educators is necessitated by programmes run in higher education institutions particularly the faculty responsible for educating prospective teachers. This study has established that the institution does not hire the appropriate manpower to teach in the faculty of education and that the university does not offer higher education programmes aimed at preparing university teachers. People who are employed to teach prospective teachers often assume the responsibility of teaching without an appropriate qualification. Additionally, they rarely receive mentoring on the discourse of teaching student teachers and they therefore have to acquire the skills for teaching in higher education on the job. Lack of the discourse of teaching prospective teachers is sometimes referred to as "a role akin to an absentee landlord". The National University of Lesotho, the context for the study shared in this paper, does not seem to ponder on the criteria for employing teacher educators and what they are expected to do once they are engaged in the practice of teaching prospective teachers.

There are therefore great challenges regarding the education of teacher educators and the extent to which their career can be recognised as a distinct or well-defined profession. Studies of the teacher educators' sources of professional knowledge have to be carried out to resolve challenges posed by the lack of empirical research in this area.

Establishing the extent to which the institution employs people who are not qualified to teach prospective teachers is problematic necessitated engaging in the study. The intention was to find out whether teaching in higher education particularly in the faculty of education was a problem worth studying. The major question for undertaking this study was: What are the sources of teacher educators' professional knowledge? While there was this big question there were other questions. For purposes of this paper the relevant question asked in undertaking the study was: How do teacher educators enact professional knowledge? 


\section{Literature}

\subsection{Introduction}

The literature reviewed for this paper indicates that historically, teacher educators were not trained to teach in higher education institutions. For example, Drakensberg (2000) shares the feeling of being employed to teach teachers in a situation where one does not even have the skills that prospective teachers are expected to acquire.

I was offered an appointment as a teacher educator at a teacher education college. All of a sudden, having ... a $\mathrm{PhD}$, I was qualified as a teacher educator and qualified to tell others how to teach ... something I had never done myself. In such a situation good advice is expensive, so the friendly and nice teacher educators at that teachers' college taught me to be a teacher-educator (p.70).

Drakensberg (2000) is an example of a teacher educator who was trusted to educate prospective teachers while he did not have the expertise on undertaking the task.

The literature also refers to the context in the field of teacher education or what Clandinin and Connelly (1995) refer to as "teachers' professional landscapes" which play a significant role in shaping teacher educators and their work. It is about how people think and act. Beginning with their descriptions of what the "teacher educators" consider themselves to be and later showing the relationship between the origins of their professional journeys and how the context has contributed to their ongoing journeys.

\subsection{Researching teacher education}

Research in the context of teaching is a critical area. In Loughran's (2007) view, teacher educators are required to make teaching in this context a site for inquiry. Loughran (2007) argues that it is important to understand the complex nature of teaching teaching in the context of teacher education. The complexity is embedded in the very nature of teaching itself. Therefore, as Loughran (2007) argues, teacher educators have to develop the pedagogy of teacher education. The intention in developing the pedagogy of teacher education should be to signify the relationship between teaching about teaching and learning about teaching. In such a context, teaching about teaching might be purposefully examined, described, articulated and portrayed in ways that enhance an understanding of this complex interplay.

Learning from studying one's own teaching is likely to impact on the teacher educator's understanding of the complex nature of teaching and learning (Loughran, 2005, Campbell and McNamara, 2010). Campbell and McNamara, (2010) add that self-study is a possible response to educational policy makers' demands regarding the standards and quality and that teacher educators can collaborate with secondary school teachers, own students and colleagues in order to study the practice of teacher educators teaching about teaching. Loughran (2006) sees teaching teaching as playing a complicated dual role which requires "vigilance that is perhaps not so easily apprehended in the normal day to day expectations and experiences of teacher education programmes" (p.7).

\subsection{Enacting Teaching Teaching}

There is reference to the methods of enacting teacher education. Transmissive mode of teaching, especially in the context of teaching teaching, is heavily criticised by some researchers (Bullock, 2007, Loughran, 2006 and Loughran 2007). However, the teacher educators who participated in the study whose results are shared in this paper, seemed to promote what Schön (1987) argues is an extensive bias towards a technical rationality approach to teaching. Yet as Loughran (2006) seems to argue, upholding the ideals of technical rationality promotes dependency on the part of student teachers. In contrast, teacher educators are encouraged to reduce the technical rationality and to practise making the tacit explicit which, among others, requires teacher educators to constantly involve student teachers (Loughran, 2006) in learning. These questions should actually challenge teacher educators' knowledge of practice which Loughran argues, is vital to a pedagogy of teacher education or teaching teaching. Therefore, in practice, teacher educators should, according to Bullock (2007) and Loughran (2007), endeavour to develop ways of engaging student teachers in learning.

The literature seems to suggest that teaching teaching has to be a concerted effort by all teacher educators. They could draw from established theories, such as that of Schön (1983), on the reframing of practice situations to the extent that student-teachers begin to move from "predominantly thinking about themselves" to thinking beyond their contexts. This way, even as teacher educators make reference to secondary schools, to serving teachers and to students at this level, the reframing of practice would contribute to student-teachers viewing teaching as "problematic" and not routine practices that they are probably much familiar with. 


\subsection{Authenticity}

The challenge for teacher educators, as Slabbert, De Kock and Hattingh (2009) argue, is to design an authentic quality education that encompasses all kinds and levels of learners, irrespective of place and time. Such an educational enterprise may be characterised by its aim. Therefore, if the aim of education is to maximize, to completely develop and to fully utilize the human potential through facilitating lifelong authentic learning in order to create a safe, sustainable and prosperous future for all, the actual quality is clearly expressed with an educational aim that could be regarded as universal.-

\subsection{Learning to Teach}

This paper presents research on teacher educators and, to some extent, refers to their learning to teach. Discussing learning as a consequence of experience, Stuart (1998) argues that professional learning is part of the process of human growth and development and that in the end everyone has to do his/her own learning. In the context of practical or experiential based knowledge, Cochran-Smith and Lytle (1999) refer to two conceptions of teacher learning. These are knowledge-in-practice and knowledge-of-practice. The concept knowledge-in-practice entails practical knowledge, including reflection on practice. The assumption here is that teachers learn when they demonstrate their expertise, especially in situations where they are capable of making intelligent judgments. Additionally, teachers demonstrate expertise when they are designers of rich learning interactions in a classroom context. Knowledge-of-practice is knowledge that teachers need if they are to teach well. It is knowledge that is generated when they treat their own classrooms and institutions as sites for intentional investigation. At the same time, they treat the knowledge and theory produced by others as generative material for interrogation and interpretation.

\subsection{Conclusion}

The reviewed literature discussed the teacher educators' landscape based on those who researched teacher educators in their world of work. The section below discusses the method that was used in undertaking the research.

\section{Method}

The research methodology adopted in undertaking this research is qualitative in approach, following a decision influenced by an understanding that finding an answer to the question: How do teacher educators enact professional knowledge? The answer to this complex research question could not be found by merely asking questions following a quantitative approach. I therefore concur with researchers who argue that there are times when it is appropriate to use qualitative research. In fact, Creswell (2007) puts it more succinctly when he argues that researchers conduct qualitative research because a problem or issue needs to be explored.

\subsection{Description of the Subsections}

This section of the paper describes procedure followed in undertaking the research and analysing the data. The sample procedures and the sample size are discussed.

\subsection{Sampling Procedures and Size}

A total of eight teacher educators participated in the study: 4 from the Department of Educational Foundations, 2 from Science Education and 2 from the Department of Language and Social Education. There were 6 females; 4 with PhDs, 3 with M.Ed. degrees and 1 with an M.Sc. Four of these research participants were subject specialists or curriculum specialists, in English, Geography, Science and Mathematics; 3 were from Educational Foundations; Educational Management, Instructional Supervision and Counselling, and 1 was in Educational Technology.

The choice of fewer research participants was informed by arguments on purposeful sampling strategies presented by McMillan and Schumacher (2006) as being advantageous. In these researchers' view "purposeful sampling is done to increase the utility of information obtained from small samples. ... The power and logic of purposeful sampling is that a few cases studied in depth yield many insights about the topic, ...” (p.319).

In the case of this study, having individuals in each of the three Faculty of Education departments especially coupled with subject areas, experience and gender served as an important factor.

The idea of observing teacher educators in practice was to counteract receiving information solely through selfreported data, in this case narrative data. Most importantly, observation as a qualitative data gathering technique was used to enable me to gain a deeper insight and understanding of the phenomenon being observed (Nieuwenhuis, 2007b). The purpose was to observe the research participants as they enacted professional knowledge.

The use of the video camera to capture the classroom activities helped reduce weaknesses associated with classroom observation, the major one being that observational data collection technique is by its nature highly 
selective and subjective, with a tendency to focus on a specific event or object but seldom the whole (Nieuwenhuis, 2007b).

However, McMillan and Schumacher (2006), see advantages to this approach of collecting data, since observational methods have as their primary advantage that the researcher "does not need to worry about the limitations of self-report bias, social desirability, and response set and that the information is not limited to what can be recalled accurately by the subjects" (p.208). Most importantly, as pointed out by Mercer (1991), there is a need to record very detailed classroom discourse. In doing so, the behaviour of a research participant can be recorded as it occurs naturally (McMillan \& Schumacher, 2006).

\subsection{Data Analysis}

The process of data collection particularly the observations of the research participants in practice, produced volumes of videotaped and audio-taped data. The presentation illustrates the level of availability of each research participant: Fusi: 13 observations; Hoanghoang: 13 observations; Lintle: 12 observations; Mafukuthoana: 03 observation; Masethabathaba: 21 observations; Peditta: 13 observations; Thabang: 04 observations and Zinzi:19 observations. All in all, 98 observations were made. Some research participants were, more available than others. In analysing the data, I used Eraut (1994) maps of professional knowledge in particular knowing "HOW". He equates knowing HOW with practical knowledge and that this is accomplished by analysing responses to questions such as "How do teacher educators enact professional knowledge, what kind of professional knowledge do teacher educators construct and how do they model professional knowledge?". However, for purposes of this paper the focus was on enactment of professional knowledge. Hence analysis of video and audio taped data.

The data analysis progressed in phases, with some being more time consuming and exhausting than others, although most enabled me to become familiar with and internalise the data. On the one hand transcribing the classroom observations through repeatedly watching the videotaped material meant watching the participants in practice more than once. On the other, listening to audio-taped stories and transcribing them meant going over each story at least three times. Being immersed in the transcriptions helped me to internalise the data to the extent that going through the process appeared very enriching, learning what the research participants regarded as the sources of their professional knowledge and how they applied them.

The analysis of the data provided an opportunity to thematize the information.

\section{Results}

As alluded to in the introduction of this paper, the study asked the question: where do teacher educators draw their professional knowledge from? This question was relevant in the context in which teacher educators did not have training on educating student-teachers. Response to this question indicated that they attained their professional knowledge from experience.

\subsection{An Understanding of the Concept: Teacher Educator}

The teacher educators who participated in the study were challenged to describe their understanding of teacher educator as a concept. There are two interpretations, based on the analysis of what the participants in the study believe that they are. Their descriptions centre on the knowledge that they provide to the student teachers. They assist student teachers to develop their own knowledge; they are capable of equipping student teachers with the skills which are required in the teaching profession; and they intervene in peoples' lives in order to promote change and help student teachers to unleash their potential in a manner that demonstrates worthiness in what they do. These descriptions attract potential teachers to the profession.

While their understanding of teacher educator may, to a large extent, be similar to the established descriptions of this concept, their interpretation was particularly lacking in the key areas; viewing teacher educators as researchers or as professionals of a particular competence. Yet research has revealed that over and above being instructors of learning, teacher educators are also researchers and professionals and/or scholars (Fisher, 2005; Smith, 2003) in their own right.

\subsection{The Origin of the Teacher Educators' Journeys}

The teacher educators who participated in the study were asked origins of their teacher education journey. Some joined the institution through an invitation while others joined through applying to an advertised position. Those who applied for an advertised position indicated that they found working in a university as an opportunity to assume the status of working in an institution of higher learning; One of the participants had this to say "...the choice of being a teacher educator was merely getting a better job; there was nothing more to it". 


\subsection{Potential Teacher Educators Enter Teacher Education Institutions as Invitees}

Two of the eight teacher educators who participated in the study joined the teacher education career as teaching assistants on the basis of their good performance in their undergraduate teacher education programme. Questionable though is whether the performance that was considered in inviting them was in the context of teacher education discipline or their areas of specialisation such as Mathematics Education. Even as they told their stories on how they were appointed, the criteria used are not clear. Their voices confirm this interpretation. (The names used in the study were nick names).

'Masethabathaba: "I just remember that before the end of the academic year at the time that I was to leave the University one of my lecturers called me and said, 'What would you do if you were offered a position as a Teaching Assistant?"

Zinzi: "I was just lucky, one of the lecturers said to me you are doing so well, maybe we should take you to be a Teaching Assistant".

These extracts imply that in identifying potential teacher educators, the teacher educators in the service are influenced by the performance of the student-teachers and choose the best of them to join the career. They therefore seem to serve as the "behind the door" recruiting argents for their own institution and programmes.

\subsection{Potential Teacher Educators Enter through Applying to an Advertised Post}

The study established that some teacher educators join teacher education departments through applying to an advertised post. Six participants indicated that they became teacher educators through applying to an advertised post. Their reasons were different. Some had applied because they had majored in a subject for which a teacher educator was needed while others applied because they had the opinion that they had the relevant skill. One of them had this to say:

Peditta: There were no job opportunities in the mental health department. When a job vacancy presented itself at ...., they needed a lecturer in science. I actually applied for it; in fact, I did not even think I would qualify. I did not have a professional qualification then but because I had done psychology, they thought it was a good foundation for somebody who wanted to be a teacher of teachers.

Peditta's experience indicates that some teacher educators join the teacher education fraternity accidentally. In her case, she had other plans before joining the fraternity. Her previous plan was to be in the medical profession and, specifically, to practice in mental health, either as a clinical psychologist or a medical professional.

Interaction with these participants indicated that some of them did not believe this career was what they initially thought they would follow. Therefore, the challenge was thinking beyond how they started their professional journeys and how the context in which they were shaped who they are.

\subsection{Shaped by the Context}

The context contributed to professional change amongst the participants of the study. Reference is made to one teacher educator, who was initially not in the education field but who was determined to ensure that her contribution to teacher education was directed mainly at student teachers. Peditta developed strategies for operating and coping within the teacher education context. She acknowledged that the context within which she operated as a teacher educator contributed to her professional advancement. This teacher educator became her own context; she thrived in a profession in which she accidentally found herself. This view is based on Peditta's words.

Peditta: I found that by teaching I actually satisfied the need that I had. In teaching one is actually dealing with a lot of emotional stuff, in a sense. I think that is what actually made me comfortable, ... this is something which drove me to want to do something in the medical profession and this could actually be addressed through teaching. ... Although I became a teacher educator by accident, I think I have grown to like and enjoy it and actually look for the areas where my needs will be addressed.

\subsection{Teacher Educators in Practice}

\subsubsection{Learning in Context}

This study established that teacher educators gained practical knowledge from the context; it gave them an important dimension of the training of student-teachers for it brought in the theory and practice dimensions to life. It is practicing in context that convinced them to conclude that teaching is tentative and that teachers have to be comfortable with that tentativeness. It seems the perspective that teaching is tentative is based on the experience that presented them with challenges. They seem to have been shaped by the practical context in which they operated and therefore realized that teaching is a complex undertaking. 
This study further revealed that the experiences encountered were never documented. The encounters were positive and consequently enriching although sometimes they were challenging. Although the anecdotes were never documented, the research participants, upon being interviewed acknowledged that the experiences were worthwhile. This means documenting their experiences would have facilitated sharing such knowledge as opposed to allowing it to remain tacit. Nevertheless, participating in this study enabled them to reflect on their work. Participating in the study also enabled them to experiment with the strategies for handling the classroom-based problems and using new knowledge to bear on what they were going to teach. In practice and, as observed by Korthagen, Kessels, and Koster, (2001), through their research, teacher educators tend to adhere to the domain of phronesis as they learn how to teach the prospective teachers in practice. Therefore, sharing experiential-based knowledge could have benefited colleagues and would have allowed the participants of this study to research their own teaching.

\subsubsection{Challenging Prospective Teachers}

The extent to which teacher educators challenge the student teachers' argument is based on the observation of the teacher educators in practice. They did not seem to challenge student-teachers to think about the content of the courses and the methods employed in teaching it. Challenging student-teachers to think about these two critical aspects of teaching teaching is an idea that Loughran (2007) fully articulates as challenging while it contributes towards the cognitive development of student teachers and, to a large extent, to that of teacher educators as they motivate such developments.

There are a few incidences where both the content and opportunities for the application of challenging methods of teaching it were observed. One teacher educator required the students to constantly think about how they would teach their own students. This teacher educator presented student teachers with hypothetical cases in which they critiqued the method of teaching that would have been explained in class. In this regard, the student-teachers had an opportunity to think deeply and to analyse a particular teaching method. The questions which they raised in arguing about the relevance of the method used in teaching a given topic indicated that, given the opportunity to critique their teachers' teaching, student teachers were capable of analysing the situation that they take for granted. These were rare opportunities for teacher educators to learn from. However, this study illustrated that the moments which spontaneously presented themselves for such lessons were often not seized.

Therefore, as the study illustrates, teacher educators did not involve their student teachers in significant ways. My observation was that teaching was grounded mainly in transmissive methods and, to a less extent, in interactive methods of teaching. The challenge for the teacher educators is explicit about what is expected of student-teachers and at the same time providing them with opportunities to practise what they are expected to become while they are still students.

\subsubsection{Using Technical Language}

In a teaching space setting, teacher educators demonstrated positive development by consistently using technical language. This seemed to be aimed at helping student teachers internalize the discipline language. While some of the teacher educators used technical language, more can be done. Indeed, as Crowe and Berry (2007) suggest, more can be done towards helping student teachers think like teachers. Therefore, the flip side of developing positively in this regard is that in practice, student teachers need to engage in activities that require them to think more like teachers as opposed to thinking routinely like secondary school students.

\subsubsection{Researching the Teaching of Teaching}

One area which teacher educators do not take advantage of as they practise teaching is the use of research to create knowledge. Creation of knowledge facilitates their pedagogy of teaching prospective teachers. Involvement of student-teachers in teaching enhances this opportunity. However, research on the teaching of teaching remains a challenge to the teacher educators who participated in this study. Observing them in practice and interacting with them revealed that research was not a priority in their practice. It would seem that engaging in educational research, particularly in the context of teaching teaching could contribute towards their learning more about the career that they had joined through the backdoor, created or constructed new knowledge and improved their work as teacher educators. Lingard and Renshaw (2010) advise that teacher educators should study their own contexts.

\subsection{Sources of Teacher Educators' Practical Knowledge}

Determining the sources of teacher educators' practical knowledge indicated that they operate in complex and difficult circumstances. I used the cumulative model to illustrate that although I observed some discrepancies in the study, learning did take place as the teacher educators were involved in teaching within the teacher education 
programme. It can therefore be argued that the teacher educators who participated in the study are surely not the same as they were when they entered the teacher education institution through the backdoor.

In this case the cumulative model is represented by snow balling. The small ball of snow represents academic or formal knowledge obtained from the training. The added snow is the person's experiential knowledge, what teacher educators gain from all the main experiences that they have in professional life across the varied landscapes. The snowball does not shrink but grows with each experience. Some parts of the landscape may be snow free, where teacher educators did not pick up any new professional knowledge and some may be especially snowy where professionals picked up a lot of snow. In this snow ball analogy, there are instances where teacher educators pointed to the numerous challenges in the context in which the ball rolls. These are the possible situations in which they did not gather any snow. Presumably, as the ball gains momentum and the teacher educators moved through the varied "landscape," they learned from the experiences as novice, advanced beginner, competent, proficient and eventually became experts (Eraut. 1996). It is through experience and moving gradually but with conscious movements that teacher educators could learn (Loughran, 2006). Figure 1 shows snow ball scenario.

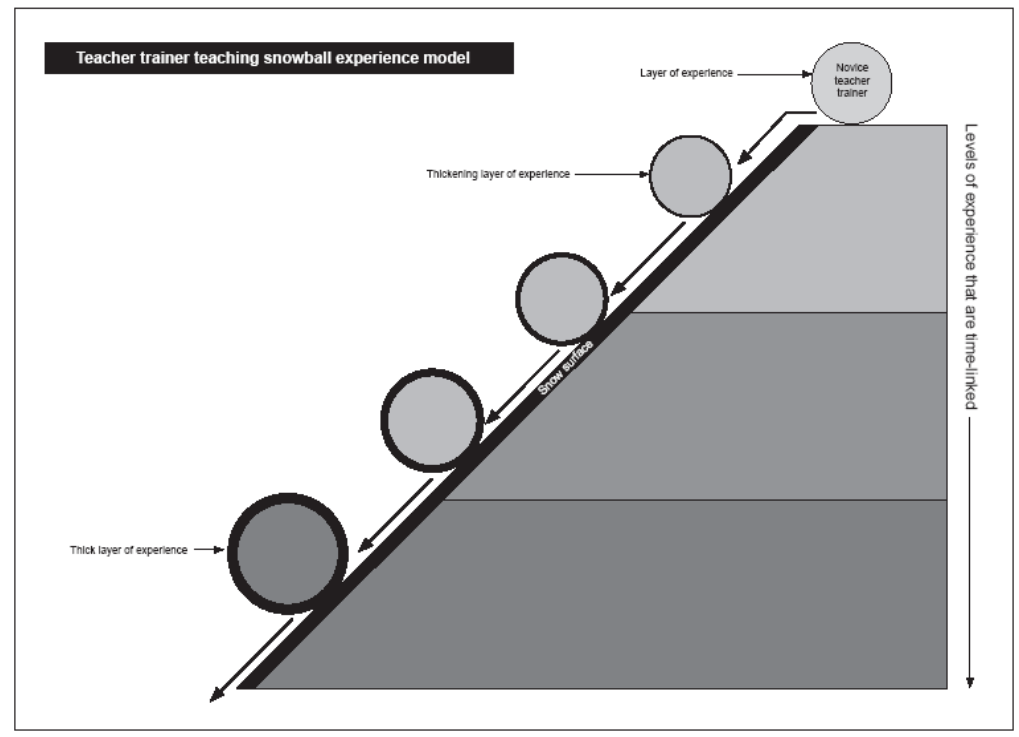

Figure 1. Teacher educator snowball experience model

\section{Discussion}

The study established that teacher educators gather experiential knowledge through practice. This view is based on observing the participants of this study in practice; they use teaching methods that were used when they were student teachers themselves. Teaching teaching cannot be viewed simplistically as just doing teaching, since it is much more than that. The nucleus of teacher education is as Shulman (2004) observes complex. Perhaps more complex than what these simple descriptions can convey.

Therefore, referring to the school system and its related matters such as what methods to use in teaching or how to teach are far from enacting "the pedagogy" of teacher education or teaching teaching. Instead, these are tips on how to teach and what the school context holds for student-teachers. Relevant here is Crowe and Barry's (2007) argument that due to the complexity of teaching, young teachers should be helped to become creative through being presented with complex situations so that they can develop strategies intended to challenge the teaching situations.

In a situation where teacher educators do not only make reference to what student teachers are likely to encounter as they enter the field of teaching, the latter are encouraged to engage in learning about teaching. In that regard, teacher educators would embrace what Lougharn (2007) refers to as being a student of teaching: knowing yourself. This is a point that Korthagen and Verkuyl (2007) tested in their own work as teacher educators. Teacher educators learn if they allow themselves to play the dual role of being learners and teachers through allowing students to critique their teaching. Lougharn (2007) argues that "students of teaching are continually confronted by struggles, difficulties and dilemmas that affect their understanding of the nature of teaching as a consequence of their experience in learning about teaching" (p.8). 
The literature pertaining to $\ldots$

Some of the challenges...

Lack of ...

\section{Conclusion}

This study established that the participants entered their teacher education career through the backdoor. They are either invited to become teaching assistants or they applied to an advertised position. Most significantly, the research participants did not have credentials for teaching in the Faculty that prepares prospective teachers for the school system. This finding might explain why they tend to use transmissive methods of teaching as opposed to interactive methods. Nevertheless, practice has, to a large extent, shaped their professional knowledge. The common feature for these teacher educators, is that they were immersed in the teaching of student-teachers, hence the snow ball cumulative model. They learned the art of teaching student-teachers in the actual context of teaching prospective teacher. It is therefore significant that the other source of professional knowledge for them is practical and/or experiential.

There is therefore a link between professional knowledge and learning from practice. It can therefore be concluded that what teacher educators use in practice is not abstract theoretical knowledge, but phronesis, which entails situation-specific principles. It is context-dependent and helps teacher educators to arrive at decisions to solve practical problems rapidly. What is important is that it helps teacher educators in practical situations to perceive what is relevant in the situation while allowing them to base their actions on their perceptions.

\section{References}

Bullock, S. M. (2007). Finding my way from Teacher-to-Teacher Educator. In T. Russell \& J. Loughran (Eds.): Enacting a Pedagogy of Teacher Education Values, Relationships and Practices, (pp77- 94). London: Routledge.

Campbell, A., \& McNamara, O. (2010). Mapping the Field of Practitioner Research, Inquiry and professional Learning in Educational Context: A Review. In A. Campbell \& S. Groundwater-Smith, Connecting Inquiry and Professional Learning in Education. London: Routledge.

Clandinin, D. J., \& Connelly F. M. (1995). Teachers' Professional Knowledge Landscapes. New York: Teachers College, Columbia University.

Cochran-Smith, M., \& Lytle, S.L. (1999). Relationships of Knowledge and Practice. Teacher Learning in Communities, Review of Research in Education, (24), 249-305. https://doi.org/10.3102/0091732X024001249

Crowe, A. R., \& Berry, A. (2007). Teaching Prospective Teachers about Learning to think like a teacher articulating our principles of practice. In T. Russell \& J. Loughran Eds.). Enacting a Pedagogy of Teacher Education Values, Relationships and Practices, (pp31-44). London: Routledge.

Drakensberg, M. (2000). A Mission for Equality among Students. In: G. Churukian \& C.R. Lock (Eds.). International Narratives on Becoming a Teacher Educator. Pp.69-72. Wales: Edwin Mellen Press.

Eraut, M. (1996). Professional Knowledge in teacher education. Address to the Finnish conference on Teacher Educators, Savonlinna.

Fisher, R. L. (2005). Standards for Teacher Educators: Preparing High-Quality Teachers. [O]. Retrieved June 2010 from http://www.Nesic.com/pub2005textframe.htm

Korthagen, F. A. J., \& Verkuyl, H. (2007). Do you Meet your Students or Yourself? Reflection on Professional Identity as an Essential Aspect of Teacher Education. In: Making a Difference in Teacher Education through Self-Study: Proceedings of the Fourth International Conference on Self-Study of Teacher Education Practice. Pp 43-47. Herstmonceaux, England:

Korthagen, F. A. J., Kessels, J., \& Koster, B. (2001). Linking Practice and Theory - the Pedagogy of Realistic Teacher Education. Mahwah, Lawrence Erlbaum Associates. https://doi.org/10.4324/9781410600523

Lingard, B., \& Renshow, P. (2010). Teaching as a Research-Informed \& Research-Informing Profession. In A. Campbell, \& S. Groundwater-Smith. Connecting Inquiry and Professional Learning in Education. Pp. 36-39. London: Routledge

Loughran, J. (2014). Professionally Developing as a Teacher Educator. Journal of Teacher Education. https://doi.org/10.1177/0022487114533386

Loughran, J. (2005). Researching Teaching about Teaching: Self-Study of Teacher Education Practices. A Journal 
of Self-Study of Teacher Education Practices, 1(1), 5-16. https://doi.org/10.1080/17425960500039777

Loughran, J. (2006). Developing a Pedagogy of Teacher Education - Understanding Teaching and Learning about Teaching. London: Routledge.

Loughran, J. (2007). Enacting a pedagogy of teacher education. In T. Russell \& J. Loughran: Enacting a Pedagogy of Teacher Education: Values, Relationships and Practices. Pp.1-15. London: Routledge.Schon, D. A. (1983). The Reflective Practitioner - How professionals Think in Action. England, Gower House.

Schon, D. A. (1987). Educating the Reflective Practitioner, San Francisco: CA, Jossey-Bass.

Shulman, L. S. (2004). The Wisdom of Practice - Essays on Teaching, Learning, and Learning to Teach. S. M. Wilson (Ed.). San Francisco: Jossey-Bass.

Slabbert, J. A., De Kock, T. M., \& Hattingh, A. (2009). The Brave 'New' World of Education CD. Cape Town: Juta.

Smith, K. (2003). So, what about professional development of teacher Educators European Journal of Teacher Educators, 2(26), 202-215. https://doi.org/10.1080/0261976032000088738

\section{Copyrights}

Copyright for this article is retained by the author(s), with first publication rights granted to the journal.

This is an open-access article distributed under the terms and conditions of the Creative Commons Attribution license (http://creativecommons.org/licenses/by/4.0/). 